\title{
IN VITRO EVALUATION OF ANTIFUNGAL ACTIVITY OF SELECTED MALAYSIAN PLANTS AGAINST THE WILT PATHOGEN OF BANANA, Fusarium oxysporum f.sp. cubense TROPICAL RACE 4
}

\author{
Pavitra Paramalingam ${ }^{1 a}$, Muhammad Salahudin Kheiril Anuar ${ }^{2 a}$, Nadiya Akmal \\ Baharum $^{3 a}$, Janna Ong Abdullah ${ }^{4 a}$, Julia Abd Aziz ${ }^{5 b}$ and Noor Baity Saidi6a,b*
}

\begin{abstract}
aDepartment of Cell and Molecular Biology, Faculty of Biotechnology and Biomolecular Sciences, Universiti Putra Malaysia, Serdang, Selangor, MALAYSIA. Email: pavitra172@gmail.com'; msalahudinanuar@gmail.com ${ }^{2}$; nadiya_baharum@upm.edu.my ${ }^{3}$; janna@upm.edu.my ${ }^{5}$; norbaity@upm.edu.my ${ }^{6}$ biodiversity Unit, Institute of Biosciences, Universiti Putra Malaysia, Serdang, Selangor, MALAYSIA. Email: julia_a@upm.edu.my ${ }^{3}$; norbaity@upm.edu.my ${ }^{4}$ *Corresponding author: norbaity@upm.edu.my Received: $8^{\text {th }}$ May 2020

Published: $30^{\text {th }}$ Jun 2021
\end{abstract}

DOI: https://doi.org/10.22452/mjs.vol40no2.2

\begin{abstract}
Fusarium wilt of banana is one of the most serious diseases affecting banana plantations worldwide. In this study, the inhibitory activities of four essential oils (clove, cinnamon, lesser alpinia and eucalyptus) and five hydrosols (kaffir lime, eucalyptus, bitter ginger, fig and tea tree) on the in vitro growth of the causal agent of the disease, Fusarium oxysporum f. sp. cubense Tropical Race 4 (TR4), were investigated. Results showed that some of these plant extracts inhibited the in vitro mycelial growth of TR4 in a dose-dependent manner. Clove oil and tea tree hydrosol were the most effective in suppressing mycelial growth in this study, the with percentage inhibition radial growth (PIRG) recorded at $46 \%$ and $69 \%$, respectively, while lesser alpinia oil and kaffir lime hydrosol showed moderate inhibition of mycelial growth with the PIRG of $33 \%$ and $64 \%$, respectively. These results suggest that these compounds have the potential to be used in future greenhouse studies as a single treatment or in combination with previously established biological control agents against Fusarium wilt of banana.
\end{abstract}

Keywords: antifungal, Fusarium oxysporum, TR4, Malaysian plants

\section{INTRODUCTION}

Bananas constitute a significant source of economic growth, food security, income and nutrition for many countries in the world. In Malaysia, bananas are the most planted fruit in 2019, occupying more than 30 thousand hectares of land, and are ranked second in terms of production after pineapple at 345.9 thousand metric tonnes (DOA, 2019). However, for many centuries, the banana crop and industry has been facing dramatic losses due to a disease known as Fusarium wilt or Panama disease. The disease is caused by the soil-borne fungus Fusarium oxysporum f. sp. cubense $(F o c)$. The most aggressive strain of the disease, the Tropical Race 4 (TR4), poses increased risks to banana supplies as it attacks all the commercial banana varieties on the market and has spread 
globally, affecting food security and income generation (Dita et al., 2018). TR4 is extremely difficult to manage because of its ability to survive in the soil for a long period. On finding a compatible host, it infects the xylem vessels, induces wilt and kills them (Ploetz, 2015).

So far, most of the strategies to manage TR4 have been established from limited research conducted on previous disease-causing strains. Considering the epidemiological aspects of TR4 (Bubici et al., 2019) and the monocultural nature of banana plantations, managing Fusarium wilt is difficult unless a resistant cultivar is available. Unfortunately, resistance trait is not present in any commercial banana cultivar (Pegg et al., 2019). Biological control in managing Fusarium wilt has gained interest recently, mainly because of economic, environmental and safety concerns of pesticide usage. A comprehensive review by Bubici et al. (2019) highlighted the potential of the biological control of Fusarium wilt and suggests that biocontrol can contribute greatly to limit its damage. The application of beneficial microbes together with their metabolites and/or active compounds from plant extracts in a bioformulation is one of the key factors affecting the efficacy of biocontrol.

The search for natural products with novel uses is pursued actively nowadays, particularly plant extracts or essential oils with antimicrobial properties attributable to their spectrum of secondary metabolites, such as alkaloids, terpenoids, tannins and many others. Herbs and medicinal plants, such as clove, neem, tulsi, rosemary, thyme, cinnamon and betel leaves, have been tested against Foc in several studies (Akila et al., 2011; Huang et al., 2013; Isianto and Emilda, 2011; Megane and Kamble, 2014; Gnanasekaran et al., 2015; Monteiro et al., 2013). However, none of the studies specified the Foc strains used except for Huang et al. (2012) and Akila et al. (2011) who mentioned the usage of Race 4 and Race 1, respectively. Most of the tests were conducted using plant extracts and only two studies used essential oils. Different plant compounds carry different profiles of secondary metabolites with different levels of activities. The amount and inhibitory potential of active compounds from plants are also influenced significantly by the geographical origin and environmental factors such as annual sunshine duration (Liu et al., 2016; Kumar et al., 2017).

Malaysia has a rich collection of unique medicinal plants, most of which are endemic species. The plants are known to contain diverse bioactive compounds with strong anti-inflammatory and antimicrobial activities (Abu Bakar et al., 2018). Local plant species, namely, kaffir lime, eucalyptus, bitter ginger, fig, tea tree, clove, cinnamon and lesser alpinia, are known to possess such bioactive compounds. However, their potential in inhibiting TR4 is not yet known.

The objective of this study was to evaluate the inhibitory activities of four essential oils (clove, cinnamon, lesser alpinia and eucalyptus) and five hydrosols (kaffir lime, eucalyptus, bitter ginger, fig and tea tree) isolated from different parts of the plant on the in vitro growth of TR4 using disc diffusion assays.

\section{MATERIALS AND METHOD}

\subsection{Fungal Material}

Fusarium oxysporum f. sp. cubense Tropical Race 4 (TR4) strain 9889 used in this study was obtained from the 
University of Malaya. The fungus was maintained on potato dextrose agar (PDA) in the dark at room temperature. For the antifungal assay, the fungus was allowed to grow for 5 days before the mycelium was harvested.

\subsection{Plant Materials and Essential Oil Isolation}

The fresh leaves of Melaleuca alternifolia (tea tree), Ficus carica (fig), Cinnamomum verum (cinnamon) and Eucalyptus globulus (eucalyptus), fresh rhizomes of Zingiber zerumbet (bitter ginger/lempoyang) and Alpinia conchigera (lesser alpinia/lengkuas padi), and dried flower buds of Syzygium aromaticum (clove/cengkih) were harvested from the Conservatory Park, Universiti Putra Malaysia, in the period of October to December 2019, separately. The samples were identified at the Biodiversity Unit, Institute of Biosciences, Universiti Putra Malaysia.

The leaves, rhizomes and flowers buds (500 g) were chopped into small pieces ranging from 1 to $1.5 \mathrm{~cm}$ then subjected to hydrodistillation process in $3000 \mathrm{~mL}$ distilled water using a modified Clevenger type apparatus for 4 hours to produce the essential oil. The top oily layer (essential oil) was separated and dried over anhydrous sodium sulphate. The essential oil obtained was kept in sealed vials at $4{ }^{\circ} \mathrm{C}$. The aqueous layer known as the hydrosol was collected and kept in separate vials at $4{ }^{\circ} \mathrm{C}$.

\subsection{Agar Well Diffusion Assay}

The antifungal assay was conducted according to the experimental design by Abd-Elsalam and Khokhlov (2015), with a modification. The In vitro antifungal activity of selected essential oils and hydrosols was determined by measuring the growth inhibition of TR4 using agar well diffusion assays. Wells of $9.5 \mathrm{~mm}$ diameter were punched in the Petri dishes (PDA medium) using a sterile cork-borer. The treatments consisted of 3,9 and $15 \mu \mathrm{L}$ of selected essential oils following the method of Istianto and Emilda (2011) and $100 \mu \mathrm{L}$ of $100 \% \mathrm{w} / \mathrm{v}, 70 \% \mathrm{w} / \mathrm{v}$ and $50 \% \mathrm{w} / \mathrm{v}$ of hydrosol diluted with $\mathrm{ddH}_{2} \mathrm{O}$. Each treatment was added to the wells. PDA without essential oil served as the negative control for the treatment with essential oil while $100 \mu \mathrm{L}$ of $\mathrm{ddH}_{2} \mathrm{O}$ was added to the negative control plates for hydrosol treatment. PDA with $100 \mu \mathrm{L}$ of $1 \mathrm{mg} / \mathrm{mL}$ of commercial sulphur-based fungicide served as the positive control for both treatments. All plates were inoculated with 5 day old TR4 mycelial discs $(5 \mathrm{~mm})$ and incubated in the dark at room temperature. The diameter of the mycelial growth of the pathogen was recorded daily until the leading edge of the fastest growing colony in the control plate had reached the edge of the plate. The results were expressed as percentage inhibition radial growth (PIRG) and was calculated as follows:

$$
\mathrm{PIRG} \%=[(\mathrm{R} 1-\mathrm{R} 2) / \mathrm{R} 1] \times 100 \%
$$

where $\mathrm{R} 1$ = radial growth of TR4 in the negative control plate and $\mathrm{R} 2=$ radial growth of TR4 in the treatment plate.

\section{RESULTS AND DISCUSSION}

Essential oils from different local herbs and medicinal plants and the accompanying hydrosols were isolated using hydrodistillation. Their in vitro antifungal activities were tested against the banana pathogen, TR4 by the inhibition of mycelial growth, which is expressed as the 
PIGR. The average daily growth of the mycelium was recorded in Tables 1 and 2 . According to the tables, not all treatments had negative effects on the mycelial growth. The diameter of the mycelium was higher than those of the controls with certain treatments, for example, cinnamon oil, fig hydrosol and bitter ginger hydrosol. Some compounds could be beneficial for the growth of the fungus, as shown previously for Aspergillus sp., where the ethanolic extract of the medicinal plant Eugenia dysenterica $D C$ stimulates its sporulation (Malheiros et al., 2019). It is widely known that many factors influence the accumulation of secondary metabolites in plants, including species differences. Comparatively, the inhibitory activity of cinnamon oil from Cinnamomum zeylanicum (Monteiro et al., 2013) was reported to inhibit Foc, but our study using Cinnamomum verum showed the opposite.

Table 1. Daily growth of TR4 on PDA in the presence of different essential oil

\begin{tabular}{|c|c|c|c|c|c|c|c|c|}
\hline \multirow[t]{2}{*}{ Treatment } & \multirow[t]{2}{*}{$\begin{array}{l}\text { Volume ( } \\
\text { uL) }\end{array}$} & \multicolumn{7}{|c|}{ Average (cm) } \\
\hline & & $\begin{array}{c}\text { Day } \\
1 \\
\end{array}$ & $\begin{array}{c}\text { Day } \\
2 \\
\end{array}$ & $\begin{array}{c}\text { Day } \\
\mathbf{3} \\
\end{array}$ & $\begin{array}{c}\text { Day } \\
4 \\
\end{array}$ & $\begin{array}{c}\text { Day } \\
5\end{array}$ & $\begin{array}{c}\text { Day } \\
6 \\
\end{array}$ & $\begin{array}{c}\text { Day } \\
7 \\
\end{array}$ \\
\hline Negative control & - & 1.80 & 2.50 & 3.10 & 4.20 & 5.47 & 6.53 & 7.47 \\
\hline \multirow[t]{3}{*}{ Clove oil } & 3 & 1.60 & 2.27 & 2.67 & 3.57 & 4.80 & 5.43 & 6.17 \\
\hline & 9 & 1.50 & 1.93 & 2.13 & 2.63 & 3.73 & 3.90 & 4.50 \\
\hline & 15 & 1.40 & 1.77 & 1.97 & 1.97 & 2.40 & 2.53 & 2.73 \\
\hline \multirow[t]{3}{*}{ Cinnamon oil } & 3 & 1.73 & 2.50 & 3.27 & 4.83 & 6.30 & 7.57 & 8.50 \\
\hline & 9 & 1.63 & 2.43 & 3.23 & 4.77 & 6.17 & 7.53 & 8.50 \\
\hline & 15 & 1.67 & 2.53 & 3.37 & 4.80 & 6.27 & 7.63 & 8.50 \\
\hline \multirow[t]{3}{*}{$\begin{array}{l}\text { Lesser alpinia } \\
\text { oil }\end{array}$} & 3 & 1.47 & 2.10 & 2.77 & 3.90 & 4.90 & 5.93 & 6.77 \\
\hline & 9 & 1.43 & 1.93 & 2.40 & 3.53 & 4.67 & 5.70 & 6.77 \\
\hline & 15 & 1.10 & 1.60 & 2.00 & 2.90 & 3.73 & 4.60 & 5.33 \\
\hline \multirow[t]{3}{*}{ Eucalyptus oil } & 3 & 1.37 & 2.30 & 2.87 & 4.10 & 5.33 & 6.77 & 7.60 \\
\hline & 9 & 1.47 & 2.27 & 3.00 & 4.13 & 5.33 & 6.93 & 7.53 \\
\hline & 15 & 1.10 & 1.90 & 2.60 & 3.90 & 5.13 & 6.40 & 7.43 \\
\hline Positive control & $1 \mathrm{mg} / \mathrm{mL}$ & 1.27 & 2.87 & 3.43 & 4.00 & 4.47 & 4.83 & 5.40 \\
\hline
\end{tabular}


Table 2. Daily growth of TR4 on PDA in the presence of different hydrosols

\begin{tabular}{|c|c|c|c|c|c|c|c|c|}
\hline \multirow[t]{2}{*}{ Treatment } & \multirow[t]{2}{*}{$\begin{array}{c}\text { Concentration } \\
(\% \mathrm{v} / \mathrm{v})\end{array}$} & \multicolumn{7}{|c|}{ Average (cm) } \\
\hline & & $\begin{array}{l}\text { Day } \\
1\end{array}$ & $\begin{array}{l}\text { Day } \\
2\end{array}$ & $\begin{array}{l}\text { Day } \\
\mathbf{3} \\
\end{array}$ & $\begin{array}{l}\text { Day } \\
4\end{array}$ & $\begin{array}{l}\text { Day } \\
5\end{array}$ & $\begin{array}{l}\text { Day } \\
6\end{array}$ & $\begin{array}{l}\text { Day } \\
7\end{array}$ \\
\hline $\begin{array}{l}\text { Negative } \\
\text { control }\end{array}$ & $\begin{array}{l}100 \mu \mathrm{L} \\
\mathrm{ddH}_{2} \mathrm{O}\end{array}$ & 1.40 & 3.07 & 3.67 & 4.20 & 4.60 & 4.87 & 5.40 \\
\hline \multirow[t]{3}{*}{ Kaffir lime } & 100 & 0.00 & 1.23 & 1.53 & 1.77 & 1.87 & 2.00 & 2.27 \\
\hline & 70 & 0.80 & 1.03 & 1.30 & 1.40 & 1.53 & 1.57 & 1.70 \\
\hline & 50 & 0.90 & 1.20 & 1.43 & 1.63 & 2.00 & 2.10 & 2.30 \\
\hline \multirow[t]{3}{*}{ Eucalyptus } & 100 & 1.37 & 3.00 & 3.63 & 4.17 & 4.67 & 5.13 & 5.63 \\
\hline & 70 & 1.40 & 3.07 & 3.70 & 4.20 & 4.53 & 4.83 & 5.20 \\
\hline & 50 & 1.53 & 3.07 & 3.77 & 4.33 & 4.70 & 5.03 & 5.40 \\
\hline \multirow[t]{3}{*}{ Bitter ginger } & 100 & 1.40 & 3.10 & 3.73 & 4.43 & 4.93 & 5.47 & 6.20 \\
\hline & 70 & 1.47 & 3.17 & 3.80 & 4.47 & 5.00 & 5.50 & 6.17 \\
\hline & 50 & 1.43 & 3.00 & 3.73 & 4.40 & 4.90 & 5.37 & 6.00 \\
\hline \multirow[t]{3}{*}{ Fig } & 100 & 1.40 & 3.10 & 3.67 & 4.33 & 4.83 & 5.27 & 5.77 \\
\hline & 70 & 1.30 & 3.07 & 3.67 & 4.33 & 4.77 & 5.20 & 5.80 \\
\hline & 50 & 1.40 & 3.13 & 3.77 & 4.40 & 4.87 & 5.50 & 6.13 \\
\hline \multirow[t]{3}{*}{ Tea tree } & 100 & 0.23 & 1.00 & 1.17 & 1.33 & 1.47 & 1.70 & 1.87 \\
\hline & 70 & 0.83 & 1.23 & 1.60 & 2.00 & 2.23 & 2.47 & 2.83 \\
\hline & 50 & 0.93 & 1.53 & 1.83 & 2.23 & 2.60 & 2.83 & 3.30 \\
\hline Positive control & $1 \mathrm{mg} / \mathrm{mL}$ & 1.27 & 2.87 & 3.43 & 4.00 & 4.47 & 4.83 & 5.40 \\
\hline
\end{tabular}

The results of the agar-well diffusion method revealed that the maximum PIGR was obtained with clove oil (Figure 1a) and tea tree hydrosol (Figure 1b). Only treatments with inhibitory activity are shown in the graph.
In both cases, the fungitoxic effect persisted at all concentrations since day 1 . In this study, both tea tree and kaffir lime hydrosols exhibited significant inhibition at all concentrations. However, increasing the concentration of the kaffir lime hydrosol up 
to $70 \%$ did not increase its inhibitory activity compared to tea tree hydrosol, which showed an upward trend (Figure 2b). Lesser alpinia oil had moderate activity against TR4, followed by eucalyptus oil, but the effect of each concentration of the former was significant (Figure 1). Representative images of the fungus growing on PDA at day 6 after treatment are shown in Figure 2. The growth of mycelium was significantly suppressed in the treated plates compared to that in the untreated plates for the compounds with positive antifungal activity. Previously, Istianto and Emilda (2011), Monteiro et al. (2013) and Juniawan et al. (2016) showed that clove oil strongly suppressed Foc Race 4 mycelial growth and our results further confirmed their findings. Eugenol, the main active compound of clove is thought to be responsible for the fungitoxic effect (Juniawan et al., 2016). This compound has been receiving much attention owing to its different biological activities including antimicrobial, antifungal, antioxidant and many others. Recently, eugenol extract and a series of eugenol derivatives were tested against Botrytis cinerea in two independent studies where the activity of the compounds was shown to be higher than that of a commercial fungicide (Olea et al., 2019). In addition, the original compound also exhibited high potential to be used in biofungicide formulations (Šernaite et al., 2020). On the other hand, based on a literature search, this is the first report of the inhibitory activity of tea tree against Foc. Tea tree has been shown to have wide spectrum antifungal activity against Fusarium species and several other plant pathogens (Terzi et al., 2007; de Andrade Santiago et al., 2018; Krzyśko-Łupick et al., 2020).

a)

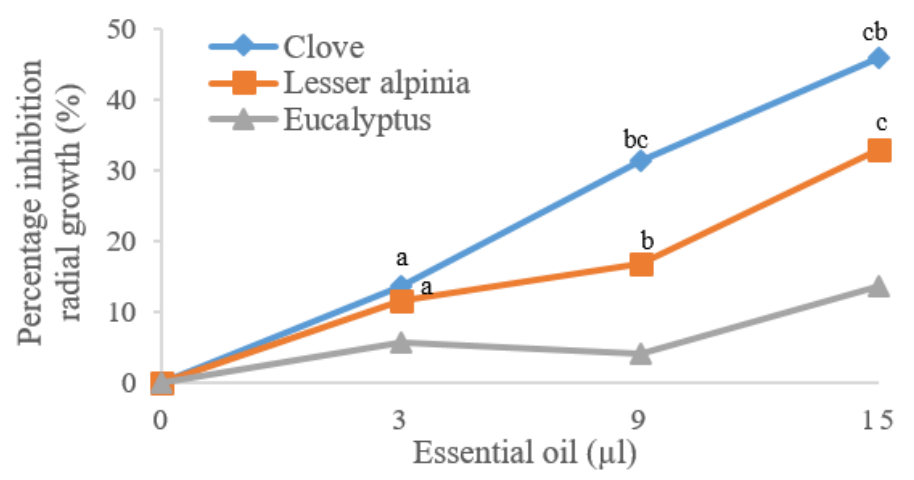

b)

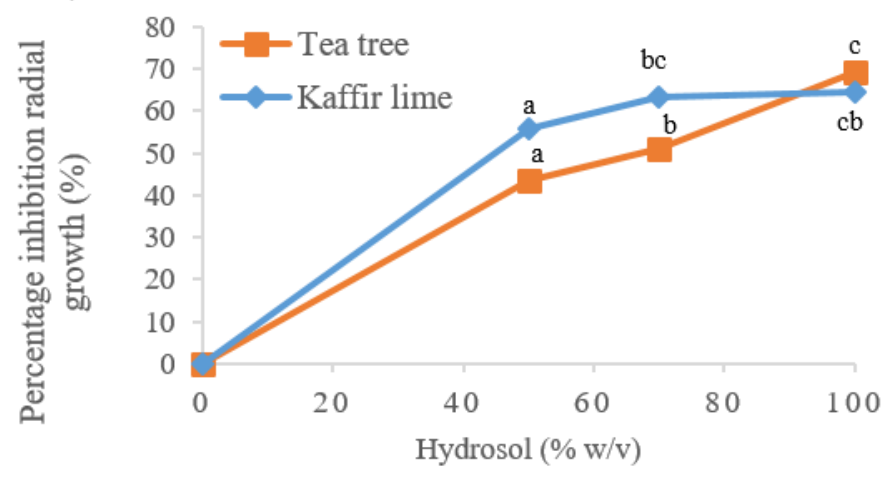

Figure 1. Antifungal efficacies of different essential oils and hydrosols against the in vitro mycelial growth of TR4. Significant inhibition $(p<0.05)$ is shown by the lower case letters. 
a)

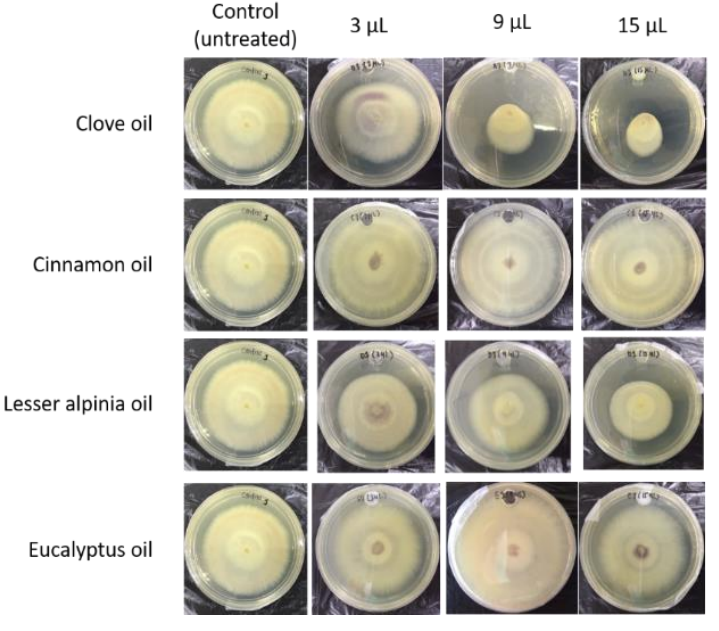

b)

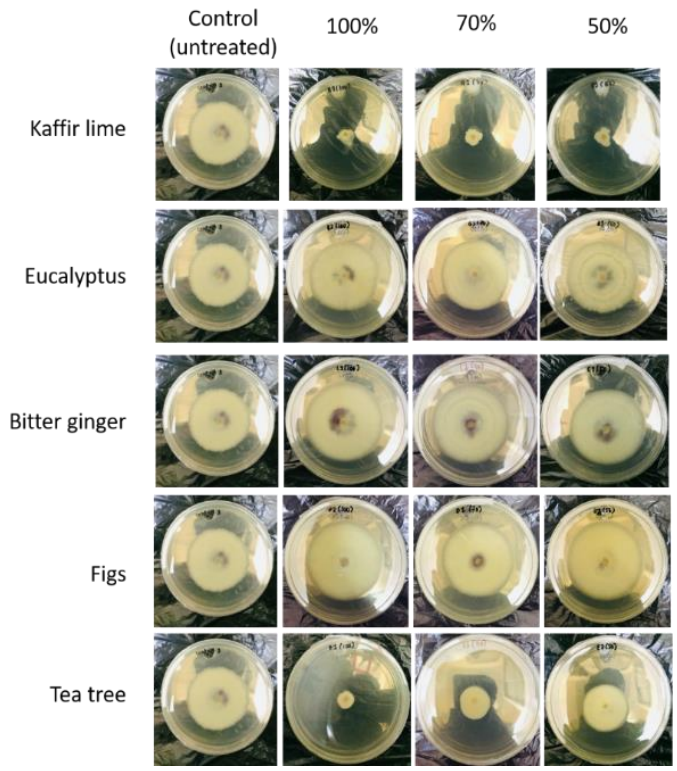

Figure 2. Colonies of TR4 observed at day 6 after treatment with different essential oils (a) and hydrosols (b)

The most active agent of tea tree is terpinen-4-ol and together with its other major components, tea tree inhibits microbial growth by inhibiting of cellular respiration leading to loss of the homeostatic balance (Oliva et al., 2003). In another study, tea tree extract was shown to inhibit fungitoxin biosynthesis (de Andrade Santiago et al., 2018). As a plant extract is composed of many elements with complex chemical composition, the identification of specific bioactive compounds responsible for the inhibitory activity of plant extracts through various chromatography techniques will pave the way for a more targeted approach in antifungal research (Altemimi et al., 2017).

\section{CONCLUSION}

This study highlighted the in vitro antifungal activities of the essential oils of clove, cinnamon, lesser alpinia and eucalyptus, as well as the hydrosols of kaffir lime, eucalyptus, bitter ginger, fig and tea tree. The results indicated that clove oil and tea tree hydrosol have strong antifungal activities against TR4, which could be used in future greenhouse studies on Fusarium wilt of banana. The identification of bioactive compounds is also worth being performed in the future to characterise their specific inhibitory potential. Although, the antifungal activities of lesser alpinia oil and kaffir lime hydrosol are moderately effective, their activities are promising. However, cinnamon oil, both eucalyptus oil and hydrosol, fig hydrosol failed to show any antifungal activities.

\section{ACKNOWLEDGEMENT}

This research was supported by Ministry of Education, Malaysia (FRGS/1/2019/STG03/UPM/02/7).

\section{REFERENCES}

Abd Elsalam K.A. and Khokhlov A.R. (2015) Eugenol oil nanoemulsion: 
antifungal activity against Fusarium oxysporum f. sp. vasinfectum and phytotoxicity on cottonseeds. Applied Nanosci 5: 255-265

Abu Bakar, F.I., Abu Bakar, M.F., Abdullah, N., Endrini, S., Rahmat, A. (2018) A review of Malaysian medicinal plants with potential antiinflammatory activity. Adv Pharmacol Sci 2018: 8603602

Akila R., Rajendran L., Harish S., Saveetha K., Raguchander T., Samiyappan R. (2011) Combined application of botanical formulations and biocontrol agents for the management of Fusarium oxysporum f. sp. cubense (Foc) causing Fusarium wilt in banana. 57: $175-183$

Altemimi, A., Lakhssassi, N., Baharlouei, A., Watson, D.G., Lightfoot, D.A. (2017) Phytochemicals: Extraction, isolation, and identification of bioactive compounds from plant extracts. Plants. 6: 42.

Bubici G., Kaushal M., Prigigallo M.I., Cabanas C.G-L., Mercado-Blanco J. (2019) Biological control agents against Fusarium wilt of banana. Front Microbiol 10: 616

de Andrade Santiago, J., Cardoso, M.D.G., Batista, L.R., Santiago, W.D., Passamani, F.R.F., Rodrigues, L.M.A., Nelson, D.L. (2018) Effect of the essential oils from Melaleuca alternifolia, Melaleuca quinquenervia and Backhousia citriodora on the synthesis of ochratoxin A by Aspergillus niger and Aspergillus carbonarius isolated from tropical wine grapes. $\mathrm{J}$ Food Sci Technol. 55: 418-213.

Dita M., Barquero M., Heck D., Mizubuti E.S.G., Staver C.P. (2018) Fusarium wilt of banana: current knowledge on epidemiology and research needs toward sustainable disease management. Front Plant Sci 9: 1468DOA (2019) Booklet Statistik Tanaman (Sub-Sektor Tanaman Makanan). Kementerian Pertanian dan Industri Asas Tani, Putrajaya, $48 \mathrm{p}$.

Gnanasekaran P., Salique S.M., Panneerselvam A., Umamagheswari K. (2015) In vitro biological control of Fusarium oxysporum $\mathrm{f}$. $\mathrm{sp}$. cubense by using some Indian medicinal plants. Int J Curr Res Acad Rev 3: 107-116

Huang Y.H., Wang R.C., Li C.H., Zuo C.W., Wei Y.R., Zhang L., Yi G.J. (2012) Control of Fusarium wilt in banana with Chinese leek. Eur J Plant Pathol 134: 87-95

Istianto M. and Emilda D. (2011) Preliminary study of the activity of some essential oils against Fusarium oxysporum f. sp. cubense. J Fruit Ornamental Plant R 19: 111-121

Juniawan, Sastrahidayat I.R., Djauhari S. (2016) Inhibition test of clove leaf oils to Fusarium oxysporum f.sp. cubense. IOSR-JAVS 9: 01-07

Krzyśko-Łupicka, T., Sokół, S., PiekarskaStachowiak, A. (2020) Evaluation of fungistatic activity of eight selected essential oils on four heterogeneous fusarium isolates obtained from cereal grains in Southern Poland. Molecules. 25: 292

Kumar S., Yadav M., Yadav J.P. (2017) Impact of spatial and climatic conditions on phytochemical diversity and in vitro antioxidant activity of Indian Aloe vera (L.) Burm.f. South African J Bot 111: 50-59

Liu W., Yin D., Li, N., Hou X., Wang D., Li D., Liu J. (2020) Influence of environmental factors on the active substance production and antioxidant activity in Potentilla 
fruticosa L. and its quality assessment 6: 28591

Malheiros R.P., de Silva Santos F., Machano L.L., Mapeli A.M. (2019) Phytochemical characterization and effect of Cagaita leaf extracts on Aspergillus Sp. Floresta Ambient 26: e20170029

Mengane S.K. and Kamble S.S. (2014) Bioefficacy of plant extracts on Fusarium oxysporum f.sp. cubense causing panama wilt of banana. Int J Pharm Bio Sci 4: 24-27

Monteiro F.P., Ferreira L.C., Silva J.L., Pacheco L.P., Souza P. E. (2013) Influence of plant extracts and essential oils against panama disease (Fusarium oxysporum f. sp. cubense) in banana seedlings. J Agri Sci 5: 63-74

Olea, A.F., Bravo, A., Martinez, R., Thomas, M., Sedan, C., Espinoza, L., Zambrano, E., Carvajal, D., Silver-Moreno, E., Carasso, H. (2019) Antifungal activity of eugenol derivatives against Botrytis Cinerea. Molecules. 24: 1239
Oliva B., Piccirilli, E., Ceddia, T., Pontieri, E., Aureli, P. andFerrini, A.M. (2003) Antimycotic activity of Melaleuca alternifolia essential oil and its major components. LettAppl Microbiol 37, 185-187

Pegg K.G., Coates L.M., O'Neill W.T., Turner D.W. (2019) The epidemiology of Fusarium wilt of banana. Front Plant Sci 10: 1395

Ploetz R.C. (2015) Fusarium wilt of banana. Phytopathol 105:15121521

Šernaitè, L., Rasiukevičiūtè, N., Valiuškaite, A. (2020) The Extracts of cinnamon and clove as potential biofungicides against strawberry grey mould. Plants(Basel). 9: 613

Terzi V., Morcia C., Faccioli P., Vale G., Tacconi G., Malnati M. (2007) In vitro antifungal activity of the tea tree (Melaleuca alternifolia) essential oil and its major components against plant pathogens. Letters App Microbiol 44: 613-618 